\title{
Petro Logical Chemical Investigations for Characterization of Marble Stones Discovered Konar-Sandal (Jiroft-Iran)
}

\author{
Parvin Soleimani ${ }^{1}$ and Seyyed Mohammad Amin Emami ${ }^{2}$ \\ 1. Young Researchers and Elite Club, Central Tehran Branch, Islamic Azad University, Tehran 13185/768, Iran \\ 2. Faculty of Conservation, Universität Siegen, Art University of Isfahan, Isfahan 1744, Iran
}

Received: March 10, 2015 / Accepted: March 25, 2015 / Published: April 25, 2015.

\begin{abstract}
Jiroft region is one of the most historical cities, placed in the southeastern of Iranian plateau. Its history dates back to the second millennium B.C. The ancient history of Jiroft and its proximity to the River of Halil Roud have attracted archeologists during the recent decades. So far various historical works have been unearthed from the region of which marble ones are especially noteworthy. Basically, marble works were used more commonly in central plateau of Iran than other ones. The marble works discovered in Jiroft region are only comparable with those from the recently excavation at Shahr-I Sokhta in Zabol. The scientific examination of such works may pave way to identify their internal structures and to compare them in terms of their provenance. The present study will focus on the characterization of marbles discovered in Konar Sandal, Jiroft. In addition to petro graphical studies, XRD and XRF investigations were used to identify the crystalline structures as well as balk chemical composition of the discovered marbles. The obtained results revealed that the major constituents of the discovered marbles in Jiroft were $\mathrm{Ca}$ and $\mathrm{CaO}$. The structure of discovered marbles had orderly compact patterns resulted mainly from metamorphism conditions. This structure is actually Unsimilar to those from Shahr-I Sokhta.
\end{abstract}

Key words: Archaeometry, Archaeology, Petrology, Marble, Jiroft.

\section{Introduction}

Jiroft, located in Kerman, Iran (Fig. 1), is considered as one of the ancient civilizations of southern east of Iran. Various objects have been unearthed in this region. For example, in archeological sites placed in southern and northern Konar Sandal region, Jiroft (Fig. 2). Different art works made of chlorite, marble and soap stones have been discovered [1].

Since, so far, little studies have been carried out on the structure of the marble stones found in this region, the present study particularly aimed to examine such stone objects in terms of structural characteristics. Although various marble stones found in Jiroft have been studied by Yousef Majidzade in terms of

Corresponding author: Parvin Soleimani, M.A Conservation of Historic Properties, research fields: restoration tile and stone. E-mail: soleimani.parvin@yahoo.com. typology and physical appearance, little attention has been paid to the internal structure of the stones [2].

Data were collected based on library and laboratory research. The latter included doing lab analyses as well as petro graphic observations in order to examine crystal phases. Instrumental analyses XRF and XRD were all done in Razi Metallurgy Centre. The Model of the system XRD was MPD (MPD Multi Purpose Device) 3000 made in Italy GNR (global network recruiting) Company and the Model of the system XRF; 8410 made in United States and ARL (animation research limited) Company. Petro graphic imaging was done in Isfahan Art University. The model of the system was Camera Dp71 Olympusbx60.

\section{Geological Overview}

Geological formations of Jiroft region date back to 


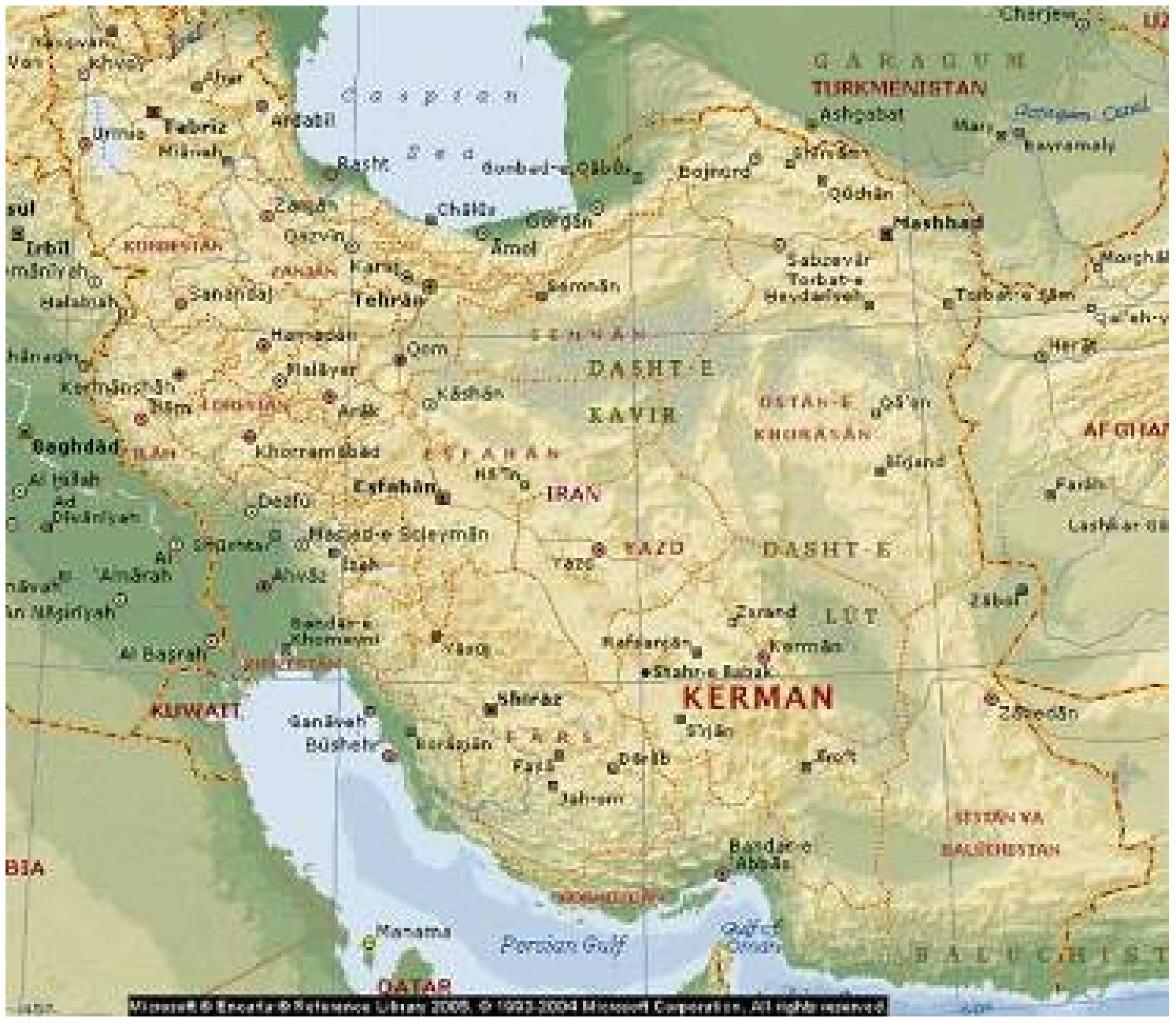

Fig. 1 Map southern east of Iran (Kerman and Zabol).

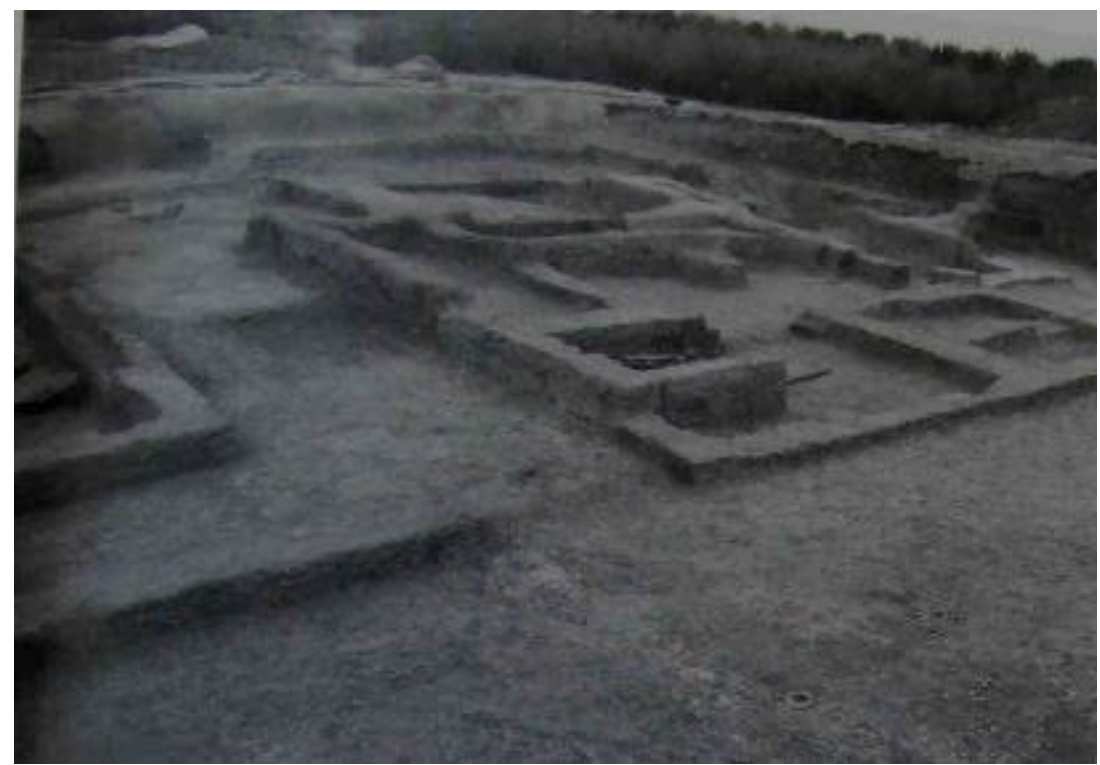

Fig. 2 Domestic architecture in Tr.VIII. photo taken from the southwest corner of the trench during the fifth season konar sandal South.

Source: [2]. 
Precambrian era up to the fourth era. In northern and eastern parts of the region, and in certain areas of the central parts, the third-era formations have been extended. Also, formations of the first and third eras can be seen in western sides of the region. The oldest formations of the region include layers of donite and Chromate undergoing high degrees of metamorphism. Also, an alternation of marble, green schist and mica schist of upper Precambrian era and Cambrian era can be observed. The profiles of these formations exist in southern and southwestern heights of Jiroft (Fig. 3).

Studying the Jiroft region, Eric Fouache and his colleagues completed and updated the activities previously done by National Cartographic Center and, at the same time, managed to prepare the geomorphologic map of Halil Roud region. Having examined the topographic conditions of the region, the group reached to the conclusion that the archeological locations of southern and northern Konar sandal belong to sedimentary plains of Halil Roud, a few hundred higher than the regional flood level. The geological variety of Halil Roud basin may be attributed to the special conditions between geological regime of Zagros and that of Makran. The western side stones of jiroft are of metamorphic kind (including schist's, marble, serpentine, Chlorite, etc.); those of eastern side of crystallized (including diorite, granodiorite, granite, etc.) and those of north side of volcanic (including andesite, volcanic ashes, etc.). In addition, northwestern and southeastern sides of the region include lime marl veins and lime stones. In southern parts of Jiroft basin, at the intersection with Jazmourian, there is a huge mass of flysch sediments [2, 3] (Figs. 4 and 5).

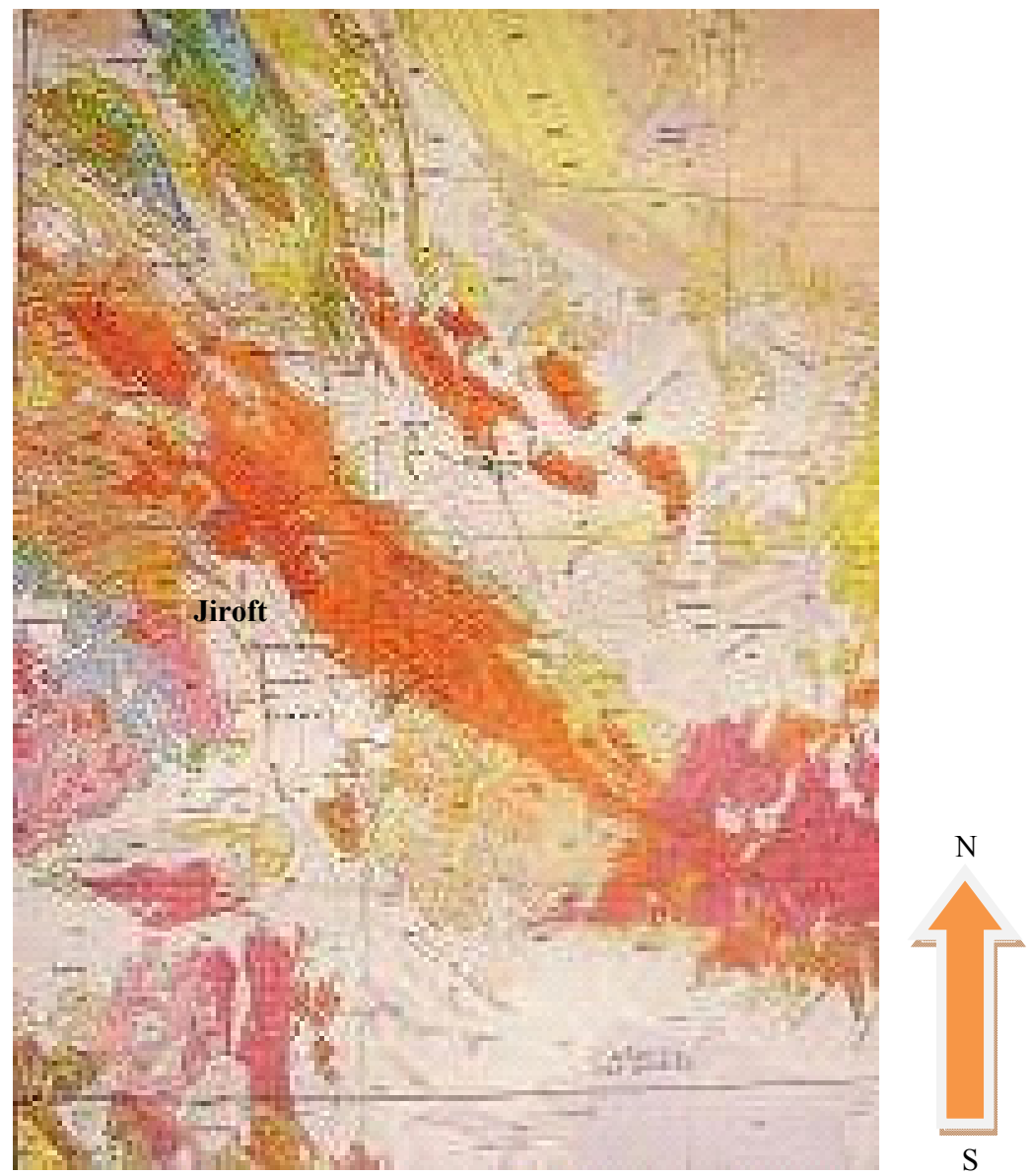

Fig. 3 Geological map of Iran sheet no 6 south-east Iran, scale: 1:1,000,000 (Source: National Iranian Oil Company Exploration and Production with considerable contributions of the Geolo Gical Survey of Iran). 


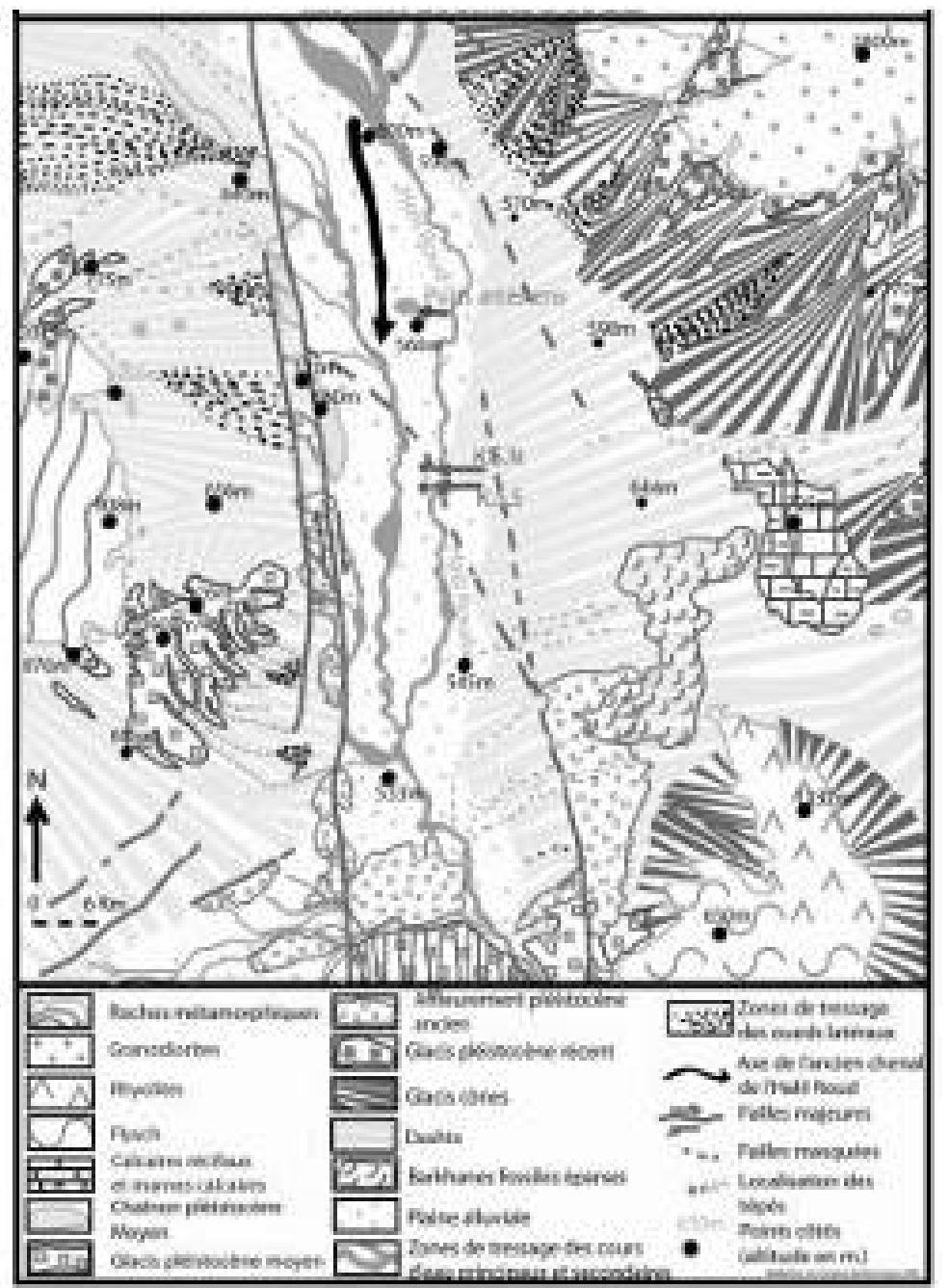

Fig. 4 Map of geomorphological features.

Source: [2].

\section{Marble Stone}

Various methods were used in order to study how temperature cycling initiates changes in the porosity of fresh and impregnated marbles. The results indicated that intergranular decohesion was more pronounced in calcitic marble than dolomite marble [4]. Marble is metamorphosed limestone and or dolomite. It is comprised mainly of calcite and dolomite [5] marble is a compact stone, in different varieties of marble the grain size varies, reaction rates vary from one variety of marble to another, other factors that would control the rate of reaction are gas concentration and relative humidity [6]. It may often contain additional accessory minerals such as brucite, diopside, epidote, clinozoisite, feldspars, forsterite, grafite, grossular, humite, pericalse, phlogopite, pyrite, quartz, scapolite, serpentine, sphene, spinel, talc, ... [5].

\section{Methodology}

The marble samples were collected from trenches at $2.5 \mathrm{~m}$ and $12 \mathrm{~m}$ depth dug in Konar Sandal region (Figs. 6 and 7). First, the samples were grouped. Then, in order to take petro graphic images, several thin films of each sample were made. Also, certain samples were ground into powder to be examined by XRF and XRD tests. The results were shown in diagrams. 


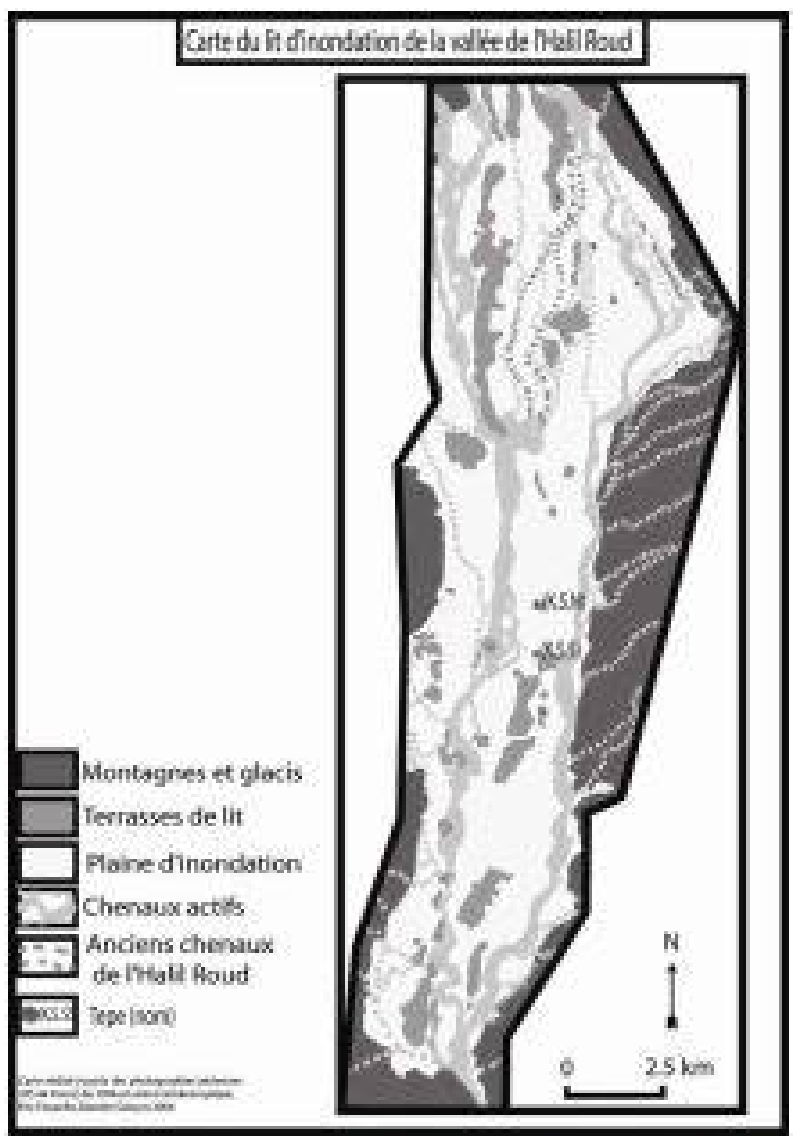

Fig. 5 Plan of information Halil Rud.

Source: [3].

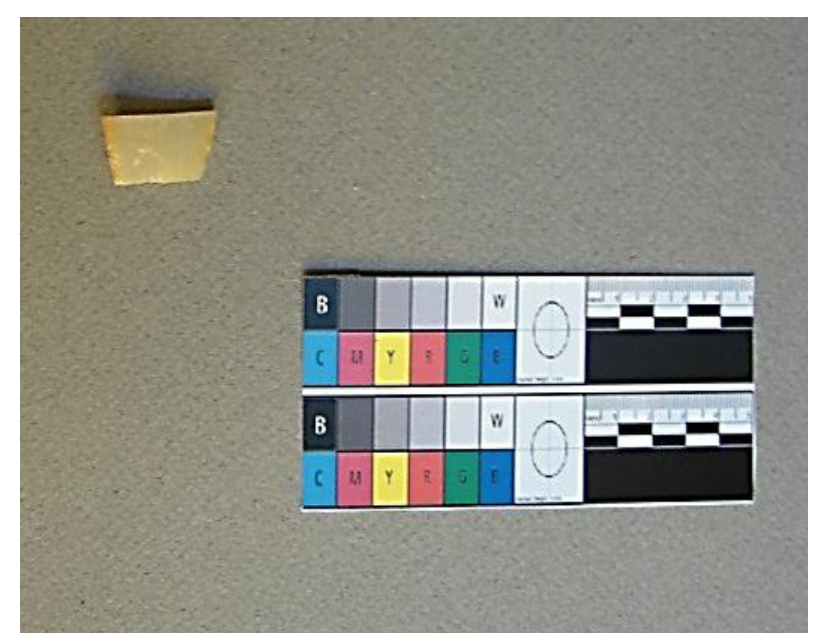

Fig. 6 Sample No. 2 stone marble, Jiroft region.

\section{Qualitative and Quantitive Studies}

In order to examine the internal structure of the historical samples, XRF analytical techniques were used so that the percentage of constituent elements and the chemical compounds of the samples could be

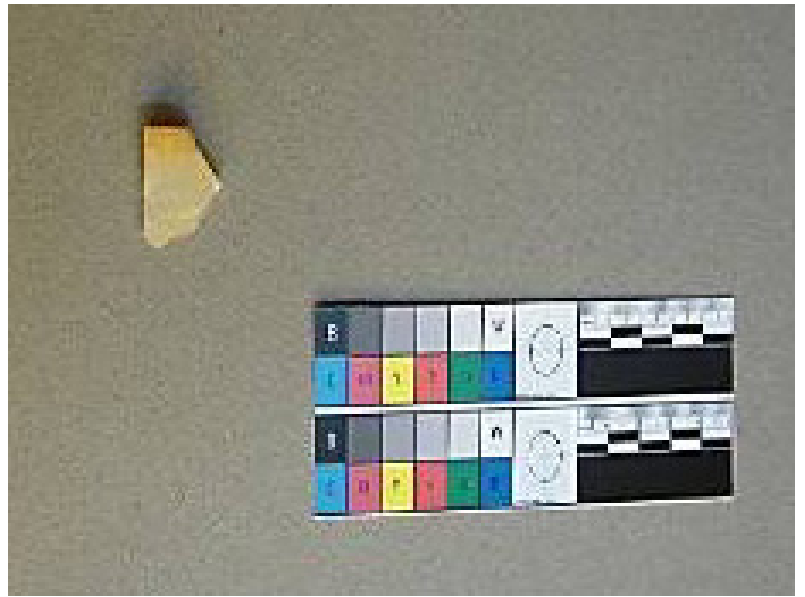

Fig. 7 Sample No. 1 stone marble, Jiroft region.

identified. The powdered samples were analyzed at Razi Metallurgy Centre. Meanwhile, XRD test was carried out to identify the predominant crystal phases. Then, in order to verify the obtained results, they were matched with microscopic observations from thin films based on petro graphic imaging.

\section{Identification of Crystal Phases Based on Petro Graphic Observations:}

Generally a petro graphic microscope-an optical-transmission microscope to be more specific - is used to identify mineral structures. When using a petro graphic microscope to identify minerals, certain principles as well as reference tables are also taken into consideration. In order that stone films can be observed by a petro graphic microscope, they should be as thick as 30 micrometer $(0.03 \mathrm{~mm})$. Such films are examined by polarized light.

Petro graphic (microscopic) observations were carried out to make sure of the results obtained from instrumental (XRF and XRD) analyses visible only to the naked eye. In most cases, the results of XRD tests were in accordance with those of petro graphic observations.

Thin section petro graphic has been widely used as a means of viewing deterioration layers on marble sculptures or architectural elements, and of aiding identification of the deterioration components [5].

(1) Sample No. 1 
Petro graphic results showed that the samples were of high quality and density and of low impurities. Also, samples contained little amount of iron compounds. There were no quartz crystals in the samples (Fig. 8). In addition, petro graphic images revealed no trace of oxidation weathering which may be explained partly by the fact that samples were not collected from the ground surface layers and consequently they were not affected by the natural humidity. Meanwhile, because the samples had no porous texture, the internal structure has remained safe from water penetration. The marble samples had a uniformly dense texture with no directional structure. No slow crystallization was visible. The samples contained mainly talc and andradite (Fig. 9).

(2) Sample No. 2

In the observed sample iron aggregates and weathering is more visible than previous sample (Fig. 10). Alongside the cracks (seen in the pictures) weathering can be seen more clearly (Fig. 11). Sample F, similar to sample one, is a compact marble. Both within the texture and on the surface of these samples, iron aggregates were visible. Generally, marble mines in Jiroft are not of weathered or metamorphic kinds, but rather they are of good quality.

\section{XRF Results Marble Samples of Jiroft ${ }^{1}$}

XRF analysis was a semi-quantitative one. ${ }^{2}$ The most prevailing elements and compounds found in the marble samples in Jiroft included Calcium (Ca) and $\mathrm{CaO}$. This analysis was done on two marble samples of Jiroft so that the constituent elements could be compared quantitively. The elements such as $\mathrm{Ca}$ (Calcium), Mg (magnesium), Mn (manganese), Al (aluminum), Si (silicon), S (sulfur), Sr (strontium) and Fe (iron) were common in both samples. Other elements, such as K (potassium) (Sample No. 2) were present only in one sample.

\footnotetext{
1 Test reference standard ASTM E 1621-05.

2 Ambient lab conditions: Temperature $25^{\circ} \mathrm{C} \&$ Relative Humidity $30 \%$.
}

\section{XRD Results Marble Samples of Jiroft ${ }^{3}$}

Studies on two marble stones found in Jiroft $^{4}$ revealed that the main constituent part of these stone was Calcite $\left(\mathrm{CaCO}_{3}\right)$ (Figs. 12 and 13).

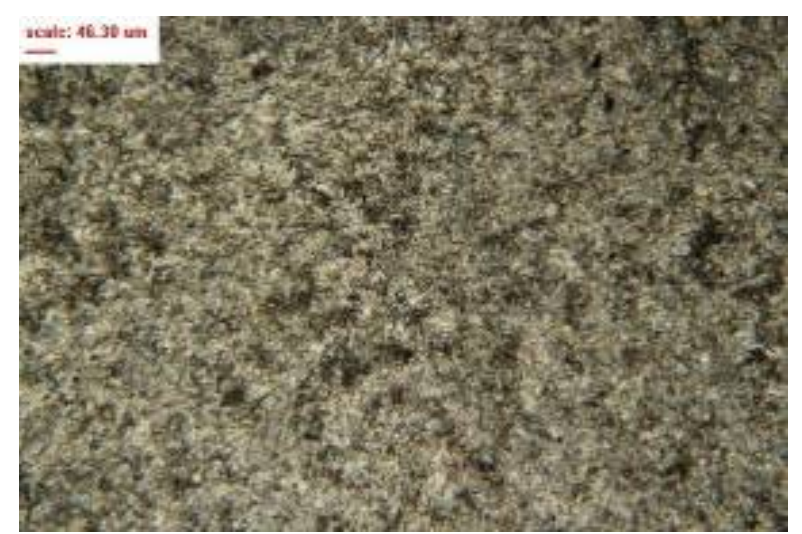

Fig. 8 Marble stone with regular structure and low porosity (sample No. 2, Jiroft) magnified 400 times.

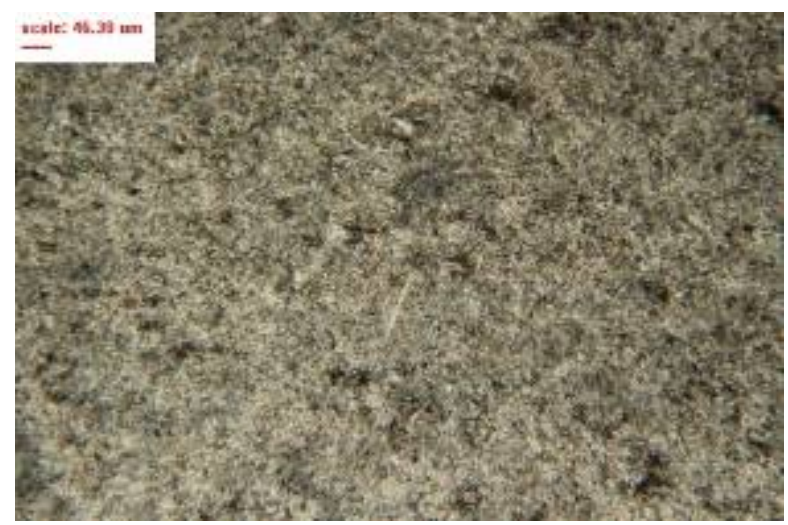

Fig. 9 Marble stone with highly dense structure (sample No. 1, Jiroft) magnified 400 times.

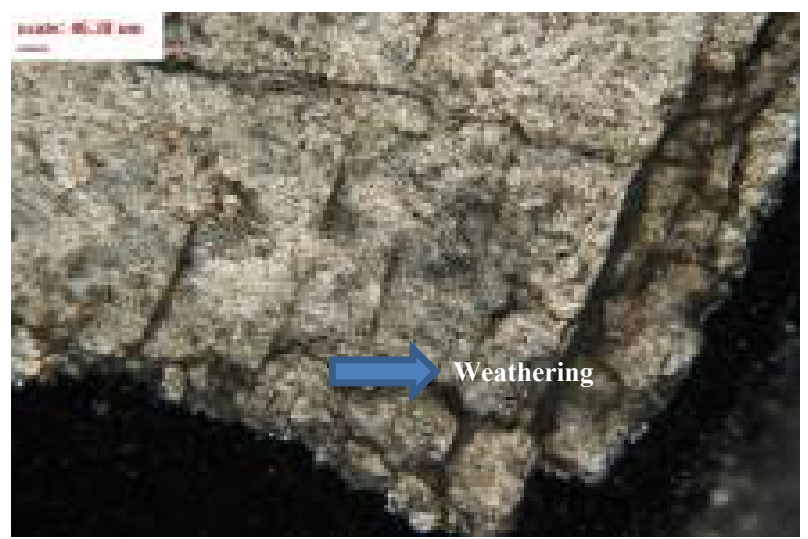

Fig. 10 Weathering Marble Sample No. 2 Jiroft region.

\footnotetext{
${ }^{3}$ Test reference standard: BS EN 13925-1 2003.

4 Ambient lab conditions: Temperature $23{ }^{\circ} \mathrm{C} \&$ Relative Humidity $50 \%$ \& Counting time: 0.5 sec\& Step Size: 0.050 \& Lamp: $\mathrm{Cu}$.
} 


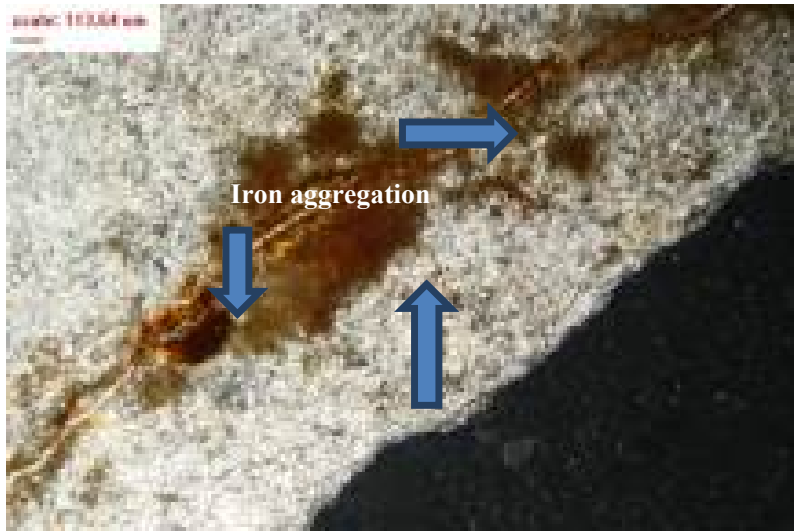

Fig. 11 Iron aggregation Sample No. 2 Jiroft region.

\section{Discussion}

Uniformly compact quality of Jiroft marble stones may be attributed to several reasons. First, the marble stones in this region have not undergone oxidation weathering. Basically, the marble samples were found from deeper layers of the ground. As a result, very low humidity in dry region of Jiroft and low porosity of the marble stones, themselves, has prevented the stones from being weathered. Second, as petro graphic images show Jiroft marble stones enjoy a uniformly compact texture; no directional structure or signs of slow crystallization can be seen. This is because, as mentioned earlier, the marbles have been formed in deep layers of the ground and as the depth decreases, the crystallization process slows down too indicating a gradual metamorphism ${ }^{5}$ (under low heat and pressure). Based on petro graphic analyses and XRD, Jiroft marbles are mainly composed of talc and arenite. Also, Jiroft marbles are of high quality and density and of low impurity (mainly ferric compounds). Petro graphic imaging revealed no trace of quartz. In addition, petro graphic imaging revealed that marble quarries of Jiroft were not of metamorphic or weathered kinds but rather of fine-grained and compact with colorful layers or with scale-shaped veins of quarts. Its chemical formula is $\mathrm{CaCO}_{3}$, and it reflects the light doubly. It is one of the mineral which

\footnotetext{
${ }^{5}$ Metamorphism also influences the final color of marbles [8]. The boundaries of the coarse crystals are sutured to embay indicating non-equilibrated metamorphic conditions [9].
}

is found in large quantity after quartz in sedimentary rocks [7].

\section{A Comparison between the Structures of Marble Stones in Jiroft and Shahre-Sokhteh}

There were few white veins on the surface of marble dishes of Jiroft. However, on the surface of marble dishes of Shahre-Sokhteh ${ }^{6}$ there were some brown and orange veins. Such a visible distinction clearly revealed the structural difference and the conditions in which the two marble stones have been formed.

Given the results of XRD and XRF tests and those of petro graphic images, it could be concluded that the two samples, most probably, were not from the same quarry. Even, it seemed unlikely that the Shahre-Sokhteh samples were from a shared part of a single quarry. Also, the marble stones of Jiroft had a high quality and a uniformly dense structure. However, those of Shahre-Sokhteh had a radically needle-like structure revealing the geographical and geological conditions in which the marble stones were formed. Although the Shahre-Sokhteh marble samples were both from the calcite class, they considerably differed from each other in terms of structure. Also, no oxidation weathering was visible in Jiroft samples.

when compared and contrasted, the two marble samples from Jiroft and Shahre-Sokhteh both placed in south east of Iran - revealed that the environmental conditions had had a determining impact on the structure of the samples forming stones chemically similar but physically and structurally very different.

\section{Conclusion}

So far, various stoneware objects (especially marble ones) have been discovered in Jiroft-an ancient

\footnotetext{
6 Shahr-I sokhta, located near to Zabol in Sistan and Baluchistan Province, the southeastern part of Iran. It is one of the main archeological sites in Iran in which archeologist have been working in recent years. Of the eminent archeologists who could manage to make significant discoveries in the site is Dr. Seyyed Mansour Sajadi who has written several articles and books in this respect [10].
} 
Table 1 Results Analysis XRF Marble stones Jiroft region.

\begin{tabular}{lllllllllll}
\hline \multirow{2}{*}{ Sample } & \multicolumn{10}{c}{ Constituent elements } \\
\cline { 2 - 12 } & $\mathrm{Fe}$ & $\mathrm{Sr}$ & $\mathrm{S}$ & $\mathrm{Si}$ & $\mathrm{Mn}$ & $\mathrm{Al}$ & $\mathrm{K}$ & $\mathrm{Mg}$ & Ca & L.O.I \\
\hline No. 1 & 2.7 & 0.084 & 0.5 & 0.08 & 0.26 & 0.08 & - & 0.40 & 36.7 & 42.04 \\
No. 2 & 3.2 & 0.079 & 0.34 & 0.10 & 0.33 & 0.11 & 0.052 & 0.31 & 36.1 & 42.66 \\
\hline
\end{tabular}

Table 2 Results analysis XRF Marble stones Jiroft region.

\begin{tabular}{|c|c|c|c|c|c|c|c|c|c|c|}
\hline Sample & $\begin{array}{l}\mathrm{Fe}_{2} \mathrm{O}_{3} \\
\% \\
\end{array}$ & $\begin{array}{l}\mathrm{SrO} \\
\% \\
\end{array}$ & $\begin{array}{l}\mathrm{SO}_{3} \\
\%\end{array}$ & $\begin{array}{l}\mathrm{SiO}_{2} \\
\% \\
\end{array}$ & $\begin{array}{l}\mathrm{MnO} \\
\%\end{array}$ & $\begin{array}{l}\mathrm{Al}_{2} \mathrm{O}_{3} \\
\% \\
\end{array}$ & $\begin{array}{l}\mathrm{K}_{2} \mathrm{O} \\
\% \\
\end{array}$ & $\begin{array}{l}\mathrm{MgO} \\
\%\end{array}$ & $\begin{array}{l}\mathrm{CaO} \\
\% \\
\end{array}$ & $\begin{array}{l}\text { L.O.I } \\
\%\end{array}$ \\
\hline No. 1 & 3.9 & 0.10 & 1.3 & 0.17 & 0.33 & 0.16 & - & 0.67 & 51.3 & 42.04 \\
\hline No. 2 & 4.6 & 0.093 & 0.84 & 0.21 & 0.43 & 0.21 & 0.063 & 0.52 & 50.4 & 42.66 \\
\hline
\end{tabular}

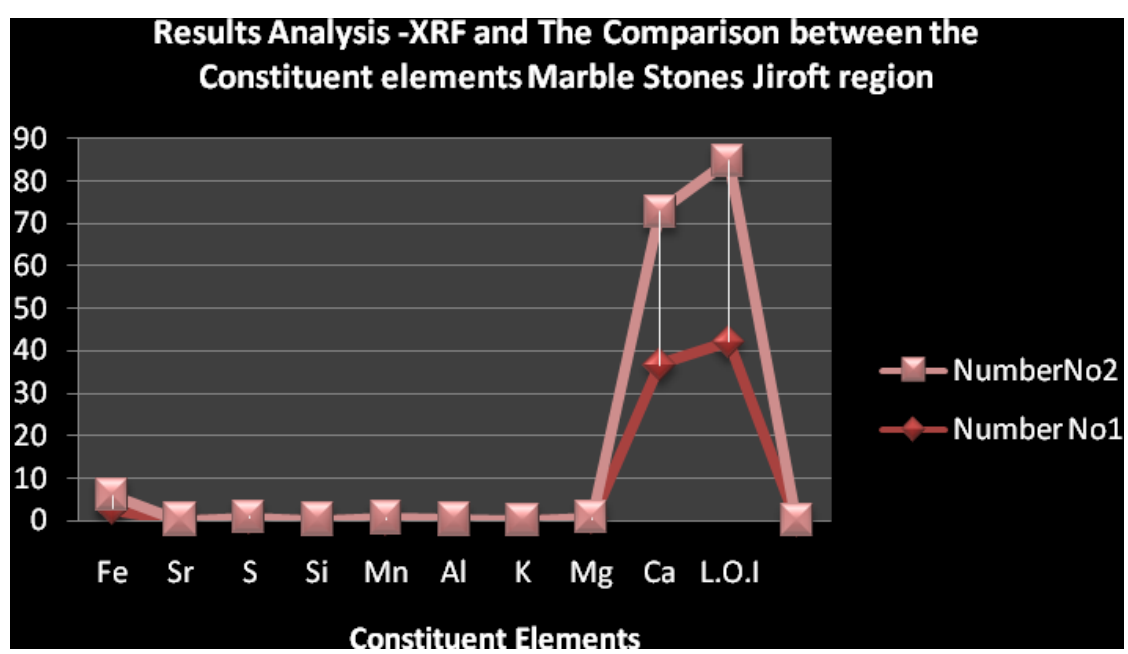

Fig. 12 Results analysis XRF and the comparison between the constituent elements Marble stones Jiroft region.

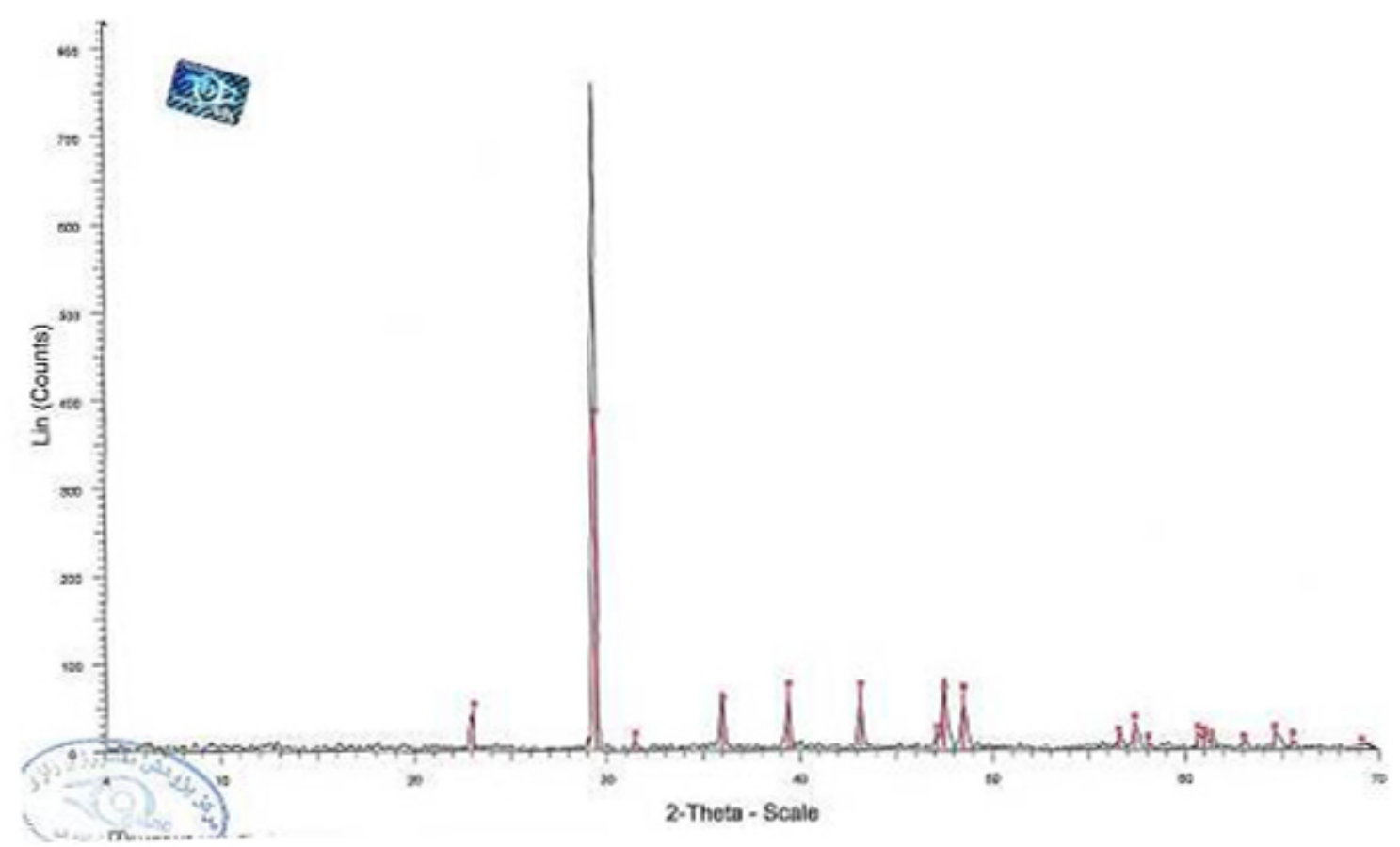

Fig. 13 Result analysis XRD of the marble stone Sample No. 1 Jiroft region. 


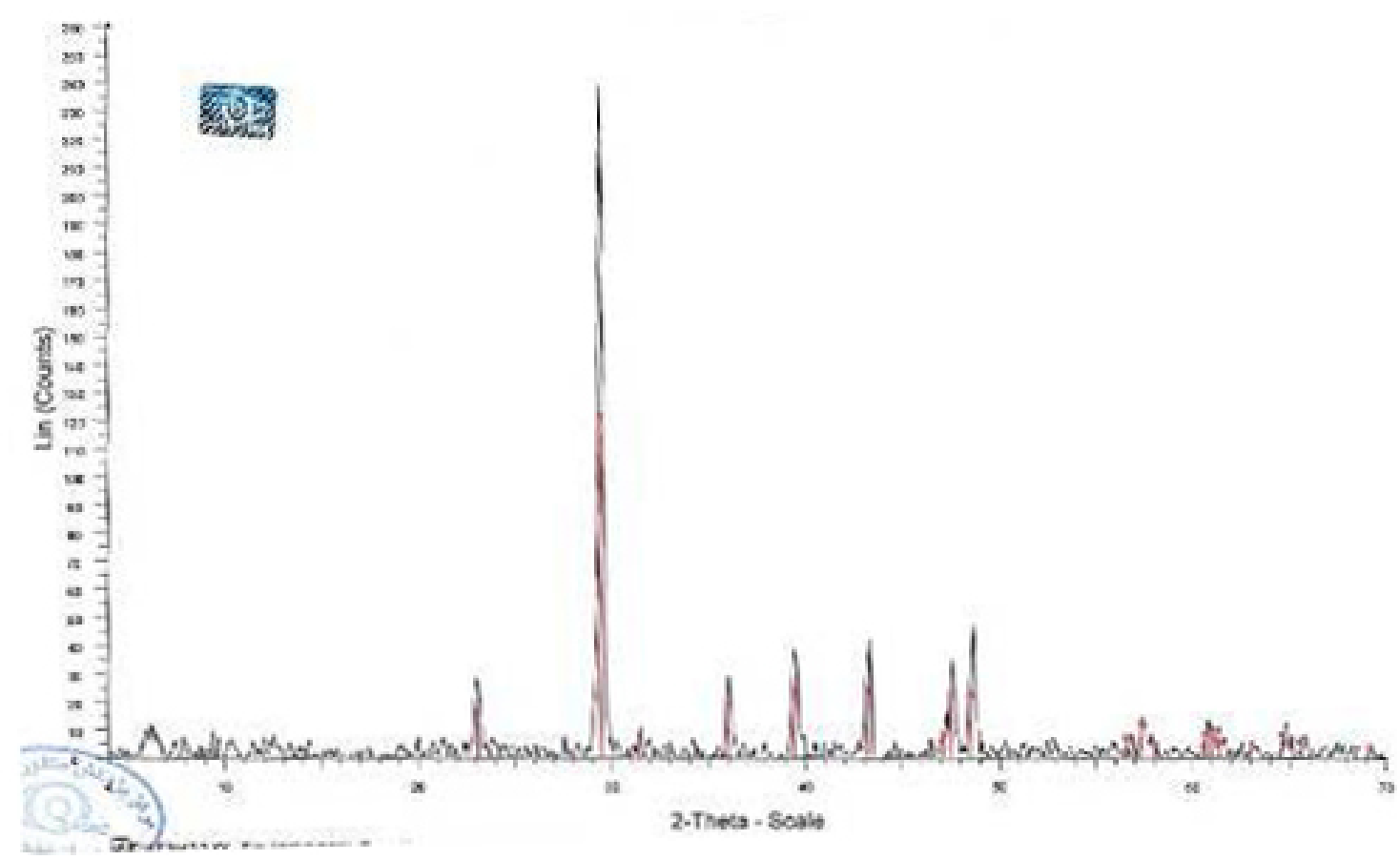

Fig. 14 Result analysis XRD of the marble stone Sample No. 2 Jiroft region.

Table 3 Describe the macroscopic and microscope Sample No. 1 (j-1).

\begin{tabular}{|c|c|c|c|c|c|c|}
\hline Sample No. & Color & Describe the macroscopic & Describe the microscope & Result XRD & Formal & Result XRF \\
\hline $\mathrm{j}-1$ & White-yellow & $\begin{array}{l}\text { Slick and thin streaks } \\
\text { yellow }\end{array}$ & Compact marble & Calcite & $\mathrm{CaCO}_{3}$ & $\mathrm{CaO}-\mathrm{Ca}$ \\
\hline
\end{tabular}

Table 4 Describe the macroscopic and microscope Sample No. 2 (j-2).

\begin{tabular}{|c|c|c|c|c|c|c|}
\hline Sample No. & Color & Describe the macroscopic & Describe the microscope & Result XRD & Formal & Result XRF \\
\hline$j-2$ & White-yellow & $\begin{array}{l}\text { Slick and thin streaks } \\
\text { yellow }\end{array}$ & Compact marble & Calcite & $\mathrm{CaCO}_{3}$ & $\mathrm{CaO}-\mathrm{Ca}$ \\
\hline
\end{tabular}

region in southeastern part of Iran. The marble wares and dishes found in the region were mainly unearthed from the archeological sites of southern Konar sandal. The marble stones of Konar sandal, Jiroft, are considerably different from those found in Shahr-e-Soukhte (the Burnt City) in respect of physical appearance.

The marble stones of Konar sandal (located in Jiroft) have few veins in white indicating the different conditions in which they were formed compared with those found in other regions. Structural characteristics were examined by XRD and XRF analyses and petro graphic imaging.

Considering XRD and XRF analyses and petro graphic imaging, Jiroft marble stone is of very high quality and enjoys a uniformly compact structure. No oxidation weathering can be seen in Jiroft marble stone - a fact that is rooted in the dry climate of the region. In sum, it can be concluded that environmental conditions have played a determining role in preserving the quality of the marble wares found in Jiroft. Meanwhile, it seems that the speed of metamorphism process has resulted in different structures of marble samples found in different regions.

\section{References}

[1] Madjidzadeh, Y. 2011. "The Six Seasons of Excavations at KonarSandal: Jiroft." Programme-Final. Accessed August 04, 2011. http://www.arch.cam.ac.uk /Shahdad/SHAHDAD.

[2] Madjidzadeh, Y. 2008. "Excavations at Konar Sandal in the Region of Jiroft in the Halil Basin: First Preliminary Report (2002-2008).” Journal of Iran XLVI: 70-3. 
[3] Foache, E. 2014. "l'approche Geoarcheologique." $\begin{array}{llll}\text { Accessed } & \text { Sept. } & 18, & \end{array}$ http://geo.unibuc.ro/revista_geomorfo/volumul12/fouach e.pdf.

[4] Starzec, K., Malaga, U., Åkesson, J. E., and Lindqvist, B. S. 2005. "Microscopic and Macroscopic Characterization of the Porosity of Marble as a Function of Temperature and Impregnation." Construction and Building Materials, 20 (10): 939-47.

[5] Reedy, C. L. 2008. "Thin-Section Petrography of Stone and Ceramic Cultural Materials." Archetype Publications, London.

[6] Gauri, K. L., and Bandyopadhyay, J. K. 1999. Carbonate Stone Chemical Behavior Durability and Conservation. New York: Wiley-Interscience Publication.
[7] Bahramzi, F. A. 2010. Structure and Interpretation of Domain Knowledge with Special Reference to Mineral Deposit in Afghanistan. A Report Submitted to the School of Engineering, Technology and Media National University.

[8] Ullah, Z., Iqbal, Y., and Rick, U. 2010. "Phase and Micro Structural Analysis of Marble from Buner District of KPK, Pakistan.” In JPMS conference Issue, Materials 2010.

[9] Al-Naddaf, M., Al-Bashaireh, K., and Al-Waked, F. 2009. "Characterization and Provenance of Marble Chancel Screens, Northern Jordan." Mediterranean Archaeology and Archaeometry 10 (2): 78.

[10] Sajjadi, M. M. S. 2003. "Excavation at Shahr-I Sokhta." Journal of IRAN XL: 21. 